Said, J., Alam, M.M., Ramli, M., \& Rafidi, M. (2017). Integrating ethical values into fraud triangle theory in assessing employee fraud: Evidence from the Malaysian banking industry. Journal of International Studies, 10(2), 170-184. doi:10.14254/2071-8330.2017/10-2/13

\title{
Integrating ethical values into fraud triangle theory in assessing employee fraud: Evidence from the Malaysian banking industry
}

\author{
Jamaliah Said \\ Universiti Teknologi MARA, \\ Shah Alam, Malaysia \\ Email:jamaliah533@salam.uitm.edu.my
}

\section{Md. Mahmudul Alam}

Universiti Utara Malaysia,

Sintok, Malaysia

Email:rony000@gmail.com

\section{Masitah Ramli \\ Universiti Teknologi MARA, \\ Shah Alam, Malaysia \\ Email: masitabramli@yahoo.com}

\author{
Marhamah Rafidi \\ Universiti Teknologi $M A R A$, \\ Shah Alam, Malaysia \\ Email: marbamahrafidi89@gmail.com
}

Abstract. This study attempts to integrate ethical values into the fraud triangle theory in the context of Malaysian banking industry. Primary data were collected through the survey of 108 questionnaires administered to the employees of the top three largest banks in Malaysia. The findings revealed that ethical values were negatively related to employee fraud, and two elements of fraud triangle theory, namely, opportunity and rationalization, were positively related to employee fraud. This implies that high ethical value is crucial to mitigate employee fraud. To minimize employee fraud, the banking industry should reduce opportunities and employee negative rationalization through strong internal control. This study contributes to literature on the occurrences of employee fraud, which is not widely discussed, especially in the context of the banking industry in developing countries.

Keywords: fraud triangle theory, banking sector, ethical value, Malaysia.

JEL Classification: G21, E59 


\section{INTRODUCTION}

Fraud is an act committed by a party or an individual for the intention of getting benefits, avoiding obligation, or causing financial or non-financial loss to another party (Ruin, 2009). Fraud is normally committed by perpetrators for personal benefit (Kennedy, 2012). The Association of Certified Fraud Examiners (ACFE) reported fraud incidents from which 36.6\% occur in the banking sector and $17.8 \%$ in the financial services with an average loss of $\$ 200,000$ (ACFE, 2014). According to KPMG (2013), the common organizational frauds relate to the cases of misappropriation of assets, misrepresentation of financial statements, theft of funds, and corruption, as well as computer-related, identity, consumer-related, and supply chain frauds.

The growing number of employee fraud is a great concern that can negatively impact balance sheets, client confidence, and staff morale (Ramazani \& Atani, 2010; Skousen \& Wright, 2006). Bank failures are as old as the banking industry itself. The Dictionary of Economics and Commerce reported that 200 banks had failed in England within 35 years, between 1815 and 1850. The failure is attributed mainly to employee fraud (Dickens et al., 1989). Employee fraud reduces the confidence of outside investors and the stability of the capital market. These instances in turn have highly impacted the growth and development of the economy, especially in the developing countries (Chen et al., 2013; Rezaee, 2005; Albrecht et al., 2010; Akindele, 2011). Scholars generally agree that employee fraud in banking continues to be a major concern for organizations of all sizes and across all regions (PWC, 2005; Klein, 2015). PWC (2005) examined the prevalence of misconduct across the industries. The survey showed that $71 \%$ of employees who work in banking were reported to have had "personally seen" or had "first-hand knowledge" of misconduct within their organization over the past 12 months. Apparently, a major portion of employee fraud cases is found in the banking sector.

Criminologists agree that fraud is caused by three elements. According to the conceptual theory by Cressey in the 1950s, the three essential elements in fraud occurrences are opportunity, pressure, and rationalization. Subsequently, many studies have tested Cressey's fraud theory, which has been conceptualized as the "fraud triangle." Although Cressey's fraud triangle has been supported by regulators, critics such as (Albercht et al., 1984; Wolfe \& Hermanson, 2004; Kranacher et al., 2010; Kassem \& Higson, 2012) have insisted that this concept will be insufficient as a tool for observing, deterring, and avoiding fraud. Thus, integration of other elements into the fraud triangle theory is necessary as fraud deterrence mechanism.

Ethical value has received much attention, especially after the highly publicized cases of Enron and WorldCom. Such cases negatively affect the economy of a country as a whole (Baker \& Andrews, 2006). In the non-financial sector, ethical values are not as important as in banking which plays a crucial part in the infrastructure of the global economy, and the issues of trustworthiness provide large implications to a country (Hartman et al., 2014). Mauritius Bankers Association Limited (2013) supported this notion by identifying strong ethical value as a cornerstone of the banking industry in performing their business. Ethical values play a significant role in reducing the likelihood of employee fraud in workplace (Cassell et al., 1997). Ziegenfuss (1996) proposed a fraud triangle theory to include ethical value implication as a reaction to the employee fraud.

In the case of Malaysia, banks suffered losses amounting to RM 789 million (185 million USD) between 2008 and 2013 due to fraud. Frequent financial frauds committed by employees include withdrawal of money from inactive accounts of customers, abuse of customer overdraft facilities, and failure to credit 
cash deposit into customer accounts (Bernama, 2016)1 ${ }^{1}$. In a recent case involving fraudulent misconduct committed by an employee of a bank, the bank employee is now facing 12 charges of theft of $\$ 35,000$ (RM 110,600). The case involved money being transferred from accounts of customers who were victims of the MH370 tragedy (Menezes, 2014).

The Global Economic Crime Survey by PWC discussed the most common types of employee fraud occurrence in the banking industry and their percentage of occurrences as follows: asset misappropriation $(69 \%)$, procurement fraud $(29 \%)$, bribery and corruption $(27 \%)$, cybercrime $(24 \%)$, and fraudulent financial statement (22\%) (PWC, 2014, p.6). Malaysia had reported the total value of fraud amounting to RM63.95 million in 2009 (KPMG Malaysia, 2009). Based on the total value of fraud disclosed, 87\% came from employee fraud occurrence, which were internally perpetrated by management and non-management sectors. This result is consistent with that in 2004.

Currently, studies on employee fraud occurrence in the banking industry are not given adequate attention by researchers. Past studies on fraud have focused on financial statement fraud (Rezaee, 2005; Hooper \& Forneli, 2010) and public sector fraud (Sanusi et al., 2015; Bakri et al., 2015) in developed countries (Smith, 2005; KPMG, 2010). Therefore, this study aims to contribute to literature by integrating the ethical value aspect into the fraud triangle theory in the context of Malaysian banking industry. This study proposes that three elements of fraud triangle theory, namely, pressure, opportunity, and rationalization, increases fraud occurrence, whereas ethical values can mitigate fraud occurrence among bank employees.

\section{LITERATURE REVIEW AND HYPOTHESIS DEVELOPMENT}

\section{Pressure and Occurrence of Employee Frand}

Fraud investigators define "pressure" as a non-observable element. This definition is particularly true for auditors who may not recognize the symptoms associated with pressure because they have often limited interactions with potential perpetrators and lack a baseline from which to evaluate current behavior (Coenen, 2007). Moreover, Hasnan et al. (2008) defined pressure in the case of financial frauds as pressure from the outside environment to meet a certain earning target, or an individually generated desire to achieve a specific financial target to earn points.

Skousen and Wright (2006) examined the role of the fraud triangle elements in detecting and predicting fraud cases. Financial stability, external pressure, personal financial needs, and financial targets have each presented pressure as the element that may be involved in the category of fraud risk factors (Skousen \& Wright, 2006).

Pressure or incentive elements will result in managers or employees committing fraud. Several researchers have found a significant relationship between pressure and fraud occurrence (Rezaee, 2005; Albrecht et al., 2010; Akindele, 2011). An individual employee will tend to commit fraud if elements of pressure, whether financial or non-financial, exist (Murdock, 2008). A survey conducted by ACFE in 2013 showed $42 \%$ of fraud activity resulted from personal financial and organization pressure (KPMG Malaysia, 2013). This finding is unanimously supported by research conducted by Abdul Rahman et al., (2016).

Dellaportas (2013) and Shelton (2014) argued that pressure plays a vital role in increasing the likelihood of fraud occurrence among bank employees. However, financial pressures may appear different depending on the position of the employee. For example, a cashier may be under personal pressure that is aligned with

\footnotetext{
${ }^{1}$ Statistical report from Bukit Aman Commercial Crimes Department released on November 1, 2016.
} 
the motive, whereas the pressure for a manager can be meeting the target as priority compared with financial pressure. This relationship is explained further by Vinten (2003), who noted that the CEO of a company may commit fraud to show escalating profits or to avoid disclosing certain liabilities in the financial statements as have been done in the Enron case. Thus, in the present study, the following relationship was hypothesized:

H1: A positive relationship exists between pressure and employee fraud in the Malaysian banking industry.

Opportunity and Occurrence of Employee Fraud

Opportunities exist when no surveillance or monitoring practices are implemented, or when weaknesses are indicated in the part of management to prevent opportunities for potential fraudsters (Ramos, 2003). Opportunity provides a chance to fraudsters to commit fraud. Many scholars (Albrecht et al., 2010; Murdock, 2008; Lister, 2007; Kassem et al., 2012; Manurung \& Hadian, 2013; Dellaportas, 2013) believe that opportunity is a very significant factor that contributes to fraud and other fraudulent activities behavior, such as embezzlement and loan manipulation, which are mostly caused by lack of internal control within the organization.

In addition, Rae and Subramaniam (2008) agreed that opportunity may generally be caused by weaknesses in the internal controls. Inadequate supervision, poor separation of duties, lack of management approval, or weak system control are examples that may provide opportunities that may result in fraud among employees (Sanusi et al., 2015). Vona (2012) identified lack of internal control as a factor that can create an opportunity as a risk assessment tool on human resources. Undeniably, opportunity can lead to intention that influences or causes someone to commit fraud.

Meanwhile, the probability of an employee to be caught is small due to the presence of opportunity in the company and leads to employees being exposed to risks of committing fraud (Cressey, 1953; Coleman, 1987; Wells, 2001; Chen et al., 2007; Lister, 2007). The findings of past studies are consistent with those of the survey conducted by PWC in 2011, which revealed opportunities, such as lack of internal control and inadequate segregation of duties, motivate employee to conduct fraudulent activities. Unfortunately, not many empirical studies are available in the context of banking industries.

In the KPMG Malaysia Fraud, Bribery, and Corruption 2013 survey, most influential opportunities presented in the workplace can lead to fraud occurrence. According to the survey, the most influential opportunities are loopholes in internal control, inadequate competency to detect fraud by the internal audit team, insufficient training to give awareness on fraud, nature of that particular industry prone to fraud, and failure to convey organizational code of ethics and values with $81 \%$, followed by bad examples portrayed by upper level staff with $43 \%$, and poor ethical culture within the organization with 38\% (KPMG, 2013). Thus, the following relationship was hypothesized:

H2: A positive relationship exists between opportunity and employee fraud in the Malaysian banking industry.

\section{Rationalization and Occurrence of Employee Frand}

Rationalization is defined as a way to legitimize a manner or concept that is incompatible with one's belief (Slezak, 2013). For example, employees who commit fraudulent financial statements may believe that their actions are in the best interest of the firms. Another example occurs when certain employees justify they have no choice but to engage in criminal acts (Cromwell \& Thurman, 2003). According to Tsang (2002), rationalization happens when the ability of a person causes him or her to reinterpret his or her deprived and wicked actions as morally acceptable.

Rationalization is a major factor that contributes to fraud (Kula et al., 2011). Cressey believes that an individual, who is a first time offender with no criminal experience, has his or her own justification to 
support his or her action. Therefore, these offenders are merely people who have found themselves entangled in difficult situations (Cressey, 1953). This finding is supported by the results of a survey conducted by KPMG in 2011 in Singapore. The results showed evidence that most first-time fraudsters rationalize their actions and do not view themselves as criminals.

According to ACFE, people tend to rationalize a criminal activity before they decide to commit the crime (ACFE, 2014). In their study, ACFE revealed that fraud in government, employees, or organizations will usually rationalize their conduct of corruption in many ways, which allow them to "innocently" carry out the act. They will tend to use excuses, such as "bribery is our country's culture," "we have no idea that the behavior is considered bribe," "we are doing this as usual," and "there is no other way to complete this."

Murphy and Dacin (2011) examined several motives that contribute to fraud occurrences among three different groups, which had evidence of fraud, perused publication on fraud, and committed fraud revealed. The findings showed that internal cultures of firms directly impact the occurrence of fraud as they present several motives and rationalizations.

Fraudsters rationalize fraud in many ways. For example, when employees steal cash from the company, they rationalize their fraudulent actions by justifying that they are only borrowing the money from the company. Other than that belief, employees rationalize their fraudulent actions by justifying that "they are only borrowing from company not stealing from their boss" (KPMG, 2003). A global economic crime survey conducted by PWC in 2011 showed 12\% of the participants believe in people's rationale to provide excuses for their actions as the largest risk of fraud (PWC, 2011). In conclusion, when rationalization is present in a workplace, the tendency to commit fraud will increase. Thus, the following relationship was hypothesized:

H3: A positive relationship exists between rationalization and employee fraud in the Malaysian banking industry.

\section{Ethical Values and Occurrence of Employee Frand}

Ethics can be defined as the agreed on standards of what is desirable and undesirable and of right and wrong conduct or behavior of a person, group, or entity (Cressy et al., 2010). Laczniak (1993) referred to ethics as acts that guide employees on the basis of moral and behavioral principles. Moreover, Ambrose et al. (2008) viewed ethical values as overall values embraced by individuals and organizations. Individual ethical values are influenced by behavior and what is thought to be right or wrong. Meanwhile, Irianto et al. (2009) referred to ethical values as being honest by following company policies and procedures. With ethical values present within themselves, any fraudulent activity may be restricted given that employees strongly believe in what is wrong and right. Mathenge (2014) examined ethical values among enforcement employees, who are found to be easily exposed to corruption. Hence, high ethical values (competence, confidence, and professionalism) will reduce the likelihood of fraudulent activities by employees in performing their job.

The existence and compliance of ethical values among employees can reduce fraud occurrence in organizations (Haron et al., 2011; Zandstra, 2002). For example, the Enron case became a point on the significance of ethical value existence. Zandstra (2002) stated that the collapse of Enron is attributed mainly to the failure of ethical responsibility. Ethical values can be established by developing and strengthening a set of ethics codes, training, top management support, compliance, and other specific ethics programs, such as hotlines, ethics groups, and staffing ethics officials (Andreoli \& Lefkowitz, 2009).

Several studies have examined the influence of ethical values on behavior and job conduct of employees (Hunt et al., 1989). Scholars propose that ethical values may reduce the tendency of employees to commit fraud (Irianto et al., 2009; Dikolli, 2012). Thus, with ethical values embraced by a company, employees will naturally give favorable responses with healthy attitudes toward work and beneficial conduct (Baker \& Andrews, 2006; Hunt et al. 1989). 
People who have established strong ethical values are attributed to exhibit ethical and integrity behavior (Rockness \& Rockness, 2005). Furthermore, with ethical values, the action employees encourage critical judgment in decision making (Zahra, 2007). Chen et al. (2013) found that employees lacking in ethical values will tend to conduct bribery and corruption. In addition, executives lacking in ethical values will tend to ignore policies and procedures to pursue their self-interests. Therefore, unethical decisions and fraudulent behavior will be likely to flourish among less ethical employees. Thus, the following relationship was hypothesized:

H4: A negative relationship exists between ethical values and employee fraud in the Malaysian banking industry.

\section{METHODOLOGY}

\section{Sampling and Data Collection}

A total of 600 questionnaires were distributed to bank employees at their respective Academic Learning Centers located in Bangi, Selangor. Respondents were given 20 minutes to fill in the questionnaire and drop the questionnaires into the box provided. Out of 600 questionnaires distributed, 108 were returned. Responses were measured on a 7-point Likert scale, ranging from strongly agree to strongly disagree.

This study was conducted among employees of three largest banks in Malaysia, which were denoted as Bank A, Bank B, and Bank C. The main criterion for selecting the three banks was based on their total asset size and market capitalization in Malaysia in 2015, as indicated by Forbes and Bursa Malaysia (2015).

○ Bank A: Bank A was established in 1960 and offers a full range of commercial, corporate, and private banking services with a network more than 450 branch offices and more than 2,500 Automated teller machines (ATMs). Apart from operating in Malaysia, Bank A also operates in Singapore, Brunei, Indonesia, Papua New Guinea, Vietnam, New York, London, and China. With 45,000 employees, Bank A has USD 183.13 billion in total asset size and USD 24.5 billion in market capitalization.

- Bank B: Bank B was established in 1965 and offers a full range of consumer banking, corporate banking, investment banking, Islamic banking, asset management, insurance, and takaful. The network has more than 1,080 branches over 18 countries. With 40,000 employees, Bank B is the second largest bank in Malaysia with USD 118.56 billion in total asset size and USD 14.5 billion in market capitalization.

○ Bank C: Bank C was established in 1966 and focuses on financial services including personal banking, commercial banking, Islamic banking, investment banking, share broking, trustee services, nominee services, sale and management of unit trust funds, banccassurance, and general insurance products. Bank $\mathrm{C}$ has a network of 259 branches and 1,801 ATMs. Its presence in the Asia Pacific region has a network of 1 subsidiary each in Hong Kong (83 branches), Cambodia (27 branches), and Vietnam ( 7 branches), 4 branches in Laos, 3 branches in China, and 3 branches in Sri Lanka. With more than 35,000 employees, Bank C has USD 98.88 billion in total asset size and USD 20.4 billion in market capitalization.

Therefore, the employees of the three banks were deemed suitable as respondents in the present study. Measurement of Variables

This study measured pressure by eight items that were adopted and modified from Wolfe and Hermanson (2004), Rezaee (2005), Kassem and Higson (2012), and Dellaportas (2013). Moreover, eight items on opportunity were designed to measure the level of weaknesses in the work environment that could 
create opportunities for employee fraud occurrence by adopting from Wolfe and Hermanson (2004), Din (2008), Kassem and Higson (2012), and Delllaportas (2013). With modifications to reflect bank employee working culture and working environment, eight items on rationalization were adopted from Marquet (2011), Tugas (2012), Kassem and Higson (2012), and Dellaportas (2013). Furthermore, eight items in the questionnaire were adopted with modifications from Galbraith and Stephenson (1993), Davis et al. (2001), and Kalshoven et al. (2011), which were designed to measure ethical values. Finally, eight items were designed to measure the level of an employee fraud in the banking industry based on Wilson (2004), Holtfrefer (2004), Din (2008), and Marquet (2011). All of these items are available in the Appendix.

Model and Statistical Test

The data were analyzed using descriptive statistics, factor analysis, and cross-sectional regression. Initially, validity of the data was tested through several standard diagnostic procedures. The adequacy of data was tested by Kaiser-Meyer-Olkin test, normality of data was tested by skewness and kurtosis analysis, and homoscedasticity of data was tested by F-test and Bartlett Sphericity test. Correlation analysis was carried out to check multicollinearity problem. Finally, the reliability of the data was tested using Cronbach's alpha test.

\section{RESULT AND FINDING}

\section{Demographic Information}

The survey showed that $35.2 \%$ (38) respondents were male and $64.8 \%$ (70) were female (Table 1). Most of the respondents $(35.2 \%, 38)$ were 30 years old and below, and in the 31-40 age group category $(38.9 \%, 42)$, while the rest was in the $41-50(18.5 \%, 20)$ age group category, and 50 years old and above $(7.4 \%, 8)$. This result indicated that the majority of the participants in this study comprised female bank employees and the age of the participants fell into the 31-40 age group category. In terms of marital status, $29.6 \%$ (32) respondents were single, $66.7 \%$ (72) were married, $2.8 \%$ (3) were divorced, and $0.9 \%$ (1) was widowed. These data showed that the majority of the respondents were married employees or had been previously married.

The results indicated that most of the bank employees in this study were educated until tertiary education, with $48.1 \%$ (52) degree holders. The next highest category of respondents was Diploma holders with $24.1 \%$ (26), followed by "O" level and other certificate holders with 17.6\% (19). A small percen tage of bank employees had postgraduate degrees of either master or doctorate qualifications with $9.3 \%$ (10). Only one respondent $(0.9 \%)$ had a professional certificate.

More than half of the respondents $(61.1 \%, 66)$ worked at the operational level and management staff, while the remaining $38.9 \%$ (42) were from the sales department. The majority of the respondents had at least 1 year or more experience as $45.4 \%$ (49) respondents were in the category of $1-5$ years of experience, followed by 38\% (41) who had more than 10 years, and 14.8\% (16) between 6 to 10 years of experience. Only $2(1.8 \%)$ respondents had worked less than one year. With regard to salary, the majority of the respondents were earning RM 2,000 to RM 5,000 (50.9\%, 55) and RM5001 to RM10000 (23.1\%, 25). Only $11.1 \%$ (12) were earning more than 10,000, while $14.8 \%$ (16) were earning less than RM 2,000 per month. 
Demographic Profile of Respondents

\begin{tabular}{|c|c|c|c|}
\hline Type & Description & Frequency & Percentage (\%) \\
\hline \multirow{2}{*}{ Gender } & Male & 38 & 35.2 \\
\hline & Female & 70 & 64.8 \\
\hline \multirow{4}{*}{ Age } & $<30$ & 38 & 35.2 \\
\hline & $31-40$ & 42 & 38.9 \\
\hline & $41-50$ & 20 & 18.5 \\
\hline & $>50$ & 8 & 7.4 \\
\hline \multirow{4}{*}{ Marital status } & Single & 32 & 29.6 \\
\hline & Married & 72 & 66.7 \\
\hline & Divorced & 3 & 2.8 \\
\hline & Widowed & 1 & 0.9 \\
\hline \multirow{5}{*}{ Level of education } & SPM/Certification & 19 & 17.6 \\
\hline & Diploma & 26 & 24.1 \\
\hline & Degree & 52 & 48.1 \\
\hline & Master/Doctorate & 10 & 9.3 \\
\hline & Professional & 1 & 0.9 \\
\hline \multirow{2}{*}{ Department } & Operation/Management & 66 & 61.1 \\
\hline & Sales staff & 42 & 38.9 \\
\hline \multirow{4}{*}{ Length of service } & $<1$ year & 2 & 1.8 \\
\hline & $1-5$ years & 49 & 45.4 \\
\hline & $6-10$ years & 16 & 14.8 \\
\hline & $>10$ years & 41 & 38 \\
\hline \multirow{4}{*}{ Salary } & $<$ RM 2,000 & 16 & 14.8 \\
\hline & RM 2,000-RM 5,000 & 55 & 50.9 \\
\hline & RM 5,001-RM 10,000 & 25 & 23.1 \\
\hline & $>$ RM 10,000 & 12 & 11.1 \\
\hline
\end{tabular}

\section{Diagnostic Test}

When confronted with large data set, exploratory data analysis should be conducted first prior to the data cleaning process. As the range of skewness values for all the variables were from -1.011 to 0.223 and that of the kurtosis was from -0.365 to 0.705 , all data were considered normal (Table 2).

Table 2

Exploratory data analysis (EDA)

\begin{tabular}{|l|c|c|c|c|}
\hline \multicolumn{1}{|c|}{ Variables } & Mean & Skewness & Kurtosis & Cronbach's Alpha \\
\hline $\begin{array}{l}\text { Employee Fraud } \\
\text { Occurrence }\end{array}$ & 2.546 & 1.235 & 0.7051 & 0.880 \\
\hline Pressure & 5.250 & -0.1612 & -0.3503 & 0.845 \\
\hline Rationalization & 4.353 & 0.2334 & -0.4642 & 0.851 \\
\hline Opportunity & 5.764 & 0.4956 & -0.6871 & 0.901 \\
\hline Ethical Values & 4.733 & 0.2306 & 0.4610 & 0.811 \\
\hline
\end{tabular}


According to Nunally (1978) and Pallant (2007), any value of 0.70 and above will be acceptable for good measure of internal consistency. The Cronbach's Alpha values for employee fraud occurrence, opportunity, pressure, rationalization, and ethical value were recorded as high as 0.880, 0.901, 0.845, 0.851, and 0.811 , respectively, which indicated good internal consistency of data.

Table 3

Pearson Correlation

\begin{tabular}{|l|c|c|c|c|c|}
\hline & $\begin{array}{c}\text { Employee } \\
\text { Fraud }\end{array}$ & $\begin{array}{c}\text { Ethical } \\
\text { Values }\end{array}$ & Pressure & Opportunity & Rationalization \\
\hline Employee Fraud & 1 & & & & \\
\hline Ethical Values & $-0.331^{*}$ & 1 & & & \\
\hline Pressure & 0.158 & 0.183 & 1 & & \\
\hline Opportunity & $0.312^{* *}$ & -0.116 & $-0.384^{* *}$ & 1 & 1 \\
\hline Rationalization & $0.426^{* *}$ & 0.081 & $0.510^{* *}$ & -0.174 & \\
\hline
\end{tabular}

Note: ${ }^{*} * \mathrm{p}<.001 ;{ }^{*} \mathrm{p}<.01$

Correlation examines the relationship between two variables in a linear fashion (Coakes et al., 2008). This analysis helps identify whether one variable is related to another. The two variables are considered highly correlated to each other and explain the dependent variable, which will cause a multicollinearity problem if the value of coefficient is 0.8 or 0.9, and above (Field, 2000). Table 3 shows the summary of the results when using bivariate analysis to test the correlation between one variable to another. The statistical results showed that the correlation values among the variables ranged from -0.384 to 0.426 . This finding indicated multicollinearity problem among the variables given that none of the correlation was more than 0.8 .

The Bartlett Sphericity test was conducted to test homoscedasticity or homogeneity of variances. The results showed that the values for employee fraud occurrence (Chi-square $=12322.087, \mathrm{p}<0.000$ ), opportunity (Chi-square $=15201.014, \mathrm{df}=21, \mathrm{p}<0.000)$, pressure $($ Chi-square $=12011.066, \mathrm{df}=21, \mathrm{p}<0.000)$, rationalization (Chi- square $=12401.014, \mathrm{df}=21, \mathrm{p}<0.000$ ), and ethical value (Chi-square $=11327.037$, $\mathrm{df}=78, \mathrm{p}<0.000)$ were noted to be statistically significant.

The Kaiser-Meyer-Olkin coefficient for these datasets was 0.788 for employee fraud occurrence, 0.893 for opportunity, 0.804 for pressure, 0.780 for rationalization, and 0.677 for ethical value, indicating that the data could be used to proceed with the exploratory factor analysis (Hair et al., 2010).

Regression Analysis

The regression showed the $\mathrm{R}$-squared $\left(\mathrm{R}^{2}\right)$ of 0.558 , which implied that the three predictor variables (opportunity, rationalization, and ethical values) explained $55.8 \%$ of the variance in employee fraud in the banking industry (Table 4). The F-statistic (40.031) and the corresponding $p$-value were highly significant (0.000).

The first objective of this study was to investigate the relationship between pressure and employee fraud. Thus, H1 proposed a positive relationship between pressure and employee fraud occurrence. As shown in Table 4, hypothesis 1 was not supported because no significant relationship was found between pressure and employee fraud occurrence $(\beta=-0.055, \mathrm{t}=-0.495, \mathrm{p}=0.622)$. Although considerable previous literature has found the association between pressure and employee fraud occurrence (e.g., Dezoort \& Lord, 1994; Dirsmirth \& Covaleski, 1985; Lord \& Dezoort, 2001), the results in this study showed statistically insignificant result. 
Output of Regression

\begin{tabular}{|l|c|c|c|c|}
\hline \multicolumn{1}{|c|}{ Variables } & Standardized coefficient & Std. Error & t-stat & p-value \\
\hline Constant & & 1.370 & 0.366 & 0.570 \\
\hline Pressure & -0.055 & 0.166 & -0.495 & 0.622 \\
\hline Opportunity & 0.243 & 0.132 & 2.447 & 0.000 \\
\hline Rationalization & 0.465 & 0.147 & 4.506 & 0.000 \\
\hline Ethical Values & -0.345 & 0.250 & -3.494 & 0.013 \\
\hline $\mathrm{R}$ & & & 0.807 & \\
\hline $\mathrm{R}^{2}$ & & & 0.558 & \\
\hline F-statistic (p-value) & & & 40.031 & \\
\hline Significance at $\mathrm{p}<0.00001$ & & & & \\
\hline
\end{tabular}

Opportunity $(\beta=0.243, \mathrm{t}=2.447, \mathrm{p}=0.000)$ was found significantly and positively correlated with employee fraud in the Malaysian banking industry. Therefore, H2 was supported. Opportunity will be present if internal control is weak within organizations (Kassem \& Higson, 2012; Wolfe \& Hermanson, 2004).

Rationalization had the largest standardized beta coefficient $(\beta=0.465, \mathrm{t}=4.506, \mathrm{p}=0.000)$. This finding indicated that rationalization made the strongest and largest contribution in explaining employee fraud occurrence in the Malaysian banking industry. Therefore, H3 was supported. Rationalization is an attitude that makes someone justify wrong behavior as acceptable. The worst case is when an individual possesses a character that allows him or her to commit fraud intentionally (Cohen et al., 2008).

The last hypothesis proposed a negative relationship between ethical values and employee fraud occurrence. Table 4 shows that the hypothesis was supported because a significantly negative relationship was indicated between ethical values and employee fraud occurrence $(\beta=-0.345, \mathrm{t}=-3.494, \mathrm{p}=0.013)$. This finding provided another insight into ethical values and its influence on employee fraud occurrence.

\section{DISCUSSION AND CONCLUSION}

The findings of this study demonstrated that opportunity, rationalization, and ethical value significantly contributed to occurrence of fraud among bank employees of Malaysia, but pressure had no significant influences on fraud.

The study revealed that the element of opportunity had a significant and positive impact on the fraud occurrence among bank employees in Malaysia. In the past, much opportunity is possible for employees to commit white collar crimes if internal control of the management is low (Kassem \& Higson, 2012; Wolfe \& Hermanson, 2004). Previous studies (Dinapoli, 2008; Omar \& Din, 2010; Lou \& Wang, 2011, and Dellaportas, 2013) have indicated that various elements, such as unclear separation of roles and responsibilities, poor documentation on policies, procedures and guidelines, insufficient physical controls by security guards, entering the transaction in an untimely manner, unrestricted access to corporate check books, and insecure control of cash boxes, present numerous opportunities for fraud to occur within the banking sector. Thus, management should emphasize on policy implementation and strengthen the power of internal control. One of the recommendations is the installation of CCTV in properties. This method can help in monitoring employee activities during office hours. Through this monitored system, employees will be aware of their actions and thus inhibit from committing fraudulent acts. Wallis \& Roselli (2015) 
agreed that the opportunity for employees to commit fraud can be reduced by strengthening the internal control of organization.

This study found that rationalization was significantly and positively related to employee fraud occurrence in the Malaysian banking industry. Rationalization has allowed individuals to justify their actions. Rationalization is in the mindset of perpetrators who justify their fraudulent acts (Mohamed et al., 2014). Wilson (2004) and Monica (2013) pointed out that employees may have their own beliefs (e.g., "I'm doing this for a good purpose," "I'm only borrowing money," "This is a return on my efforts," "Nobody will suffer as a result of this action," or "I have no outside help") that can strongly influence them to commit fraud. Organizations can promote a healthy workplace environment through enhancement of integrity courses or provision of incentives to employees who appear to possess high integrity as one of the preventive mechanism. Cash for incentives for employees will not hurt as much as large losses in the form of white collar crimes.

Finally, this study found a negative relationship between ethical values and employee fraud occurrence, thereby supporting the fourth hypothesis. Hence, high ethical values among employees result in few employee fraud occurrences. Employees tend to comply with ethical behavior during operations and services. Following ethical standards increases the belief among employees that ethical practice does not depend on situation, and thus, organization should enhance its standard code of ethics. Haron et al. (2011) agreed that the function of ethical values as influential factor can lead to fraudulent behavior among employees. Ethical values embraced individually can influence employees to abide by the organizational policies set by the management and avoid breach of rules among employees.

\section{REFERENCES}

Abdul Rahman R., Sulaiman, S., Eiman Saleh Fadel, E. S., \& Kazemian, S. (2016). Earnings Management and Fraudulent Financial Reporting: The Malaysian Story. Journal of Modern Accounting and Auditing, 12(2), 91-101.

Akindele, R. I. (2011). Fraud as a negative catalyst in the Nigerian banking industry. Journal of Emerging Trends in Economics and Management Sciences, 2(5), 357-363.

Albrecht, C., Turnbull, C., Zhang, Y., \& Skousen, C. J. (2010). The relationship between South Korean chaebols and fraud. Management Research Review, 33(3), 257-268.

Albrecht, S., Howe, K., \& Romney, M. (1984). Deterring fraud: the internal auditor's perspective. Institute of Internal Auditors Research Foundation Publisher, 1-42. ISBN 0894131176, 9780894131172

Ambrose, M. L., Arnaud, A., \& Schminke, M. (2008). Individual moral development and ethical climate: The influence of person-organization fit on job attitude. Journal Business Ethics, 77(3), 323-333

Andreoli, N., \& Lefkowitz, J. (2009). Individual and organizational antecedents of misconduct in organizations. Journal of Business Ethics, 85(3), 309-332.

Association of Certified Examiner [ACFE]. (2014). Report to the Nations on Occupational Frand and Abuse, 2014 Global Frand Study. ICFE Publisher. Retrieved from https://www.acfe.com/rttn/docs/2014-report-to-nations.pdf

Baker, T. L., Hunt, T. G., \& Andrews, M. C. (2006). Promoting ethical behavior and organizational citizenship behaviors: The influence of corporate ethical values. Journal of Business Research, 59(7), 849-857.

Bakri, H.H.M. , Said, J. Zulyanti Abd Karim Z. A. (2015). Case Study on Integrity among Royal Malaysian Police (RMP): An Ethical Perspective. Procedia Economics and Finance, 28, 121-125.

Bernama. (2016, December 7). 60\% bank fraud committed by employees. Free Malaysia Today. Retrieved from http:/ / www.freemalaysiatoday.com/category/nation/2013/12/07/60-bank-fraud-committed-by-employees/

Cassell, C., Johnson, P., \& Smith, K. (1997). Opening the black box: Corporate codes of ethics in their organizational context. Journal of Business Ethics, 16(10), 1077-1093.

Chen, J., D., Hou, W., \& Lee, E. (2013). Executive integrity, audit opinion, and fraud in Chinese listed firms. Emerging Markets Review, 15, 72-91. 
Chen, K. Y., Elder, R. J., \& Hsieh, Y. M. (2007). Corporate governance and earnings management: The implications of corporate governance best-practice principles for Taiwanese listed companies. Journal of Contemporary Accounting \&Economics, 3(2), 73-105.

Coakes, S.J., Steed, L., \& Price, J. (2008). SPSS version 15.0 for windows: Analysis without Anguish. John Wiley \& Sons Australia Ltd.

Coenen, T. (2007). The Fraud Triangle and what you can do about it. Retrieved from http://www.allbusiness.com/accounting/forensic-accounting/4968017-1.html.

Cohen, J., Ding, Y., Lesage, C., \& Stolowy, H. (2008). The role of managers' behavior in corporate fraud. Retrieved from http:/ / www.hec.fr/var/fre/storage/original/application/6b11697cf4c94a54295f85794f7fb044.PDF

Coleman, J. W. (1987). Toward an Integrated Theory of White-Collar Crime. American Journal of Sociology, 93(2), 406439.

Cressey, D. R. (1953). Other People's Money. Montclair, NJ: Patterson Smith.

Cressy, R., Cumming, D., \& Mallin, C. (2010). Entrepreneurship, governance and ethics. Entrepreneurship, Governance and Ethics, 95(2), 117-120.

Crimology. Master Dissertation. Accounting Research Institute. Universiti Tekmologi MARA.

Cromwell, P. \& Thurman, Q. (2003). 'The Devil Made Me Do It: Use of Neutralizations by Shoplifters'. Deviant Behavior, 24(6): 535-550.

Davis, M. A., Andersen, M. G., \& Curtis, M. B. (2001). Measuring ethical ideology in business ethics: A critical analysis of the ethics position questionnaire. Journal of Business Ethics, 32(1), 35-53.

Dellaportas, S. (2013). Conversations with inmate accountants: Motivation, opportunity and the fraud triangle. Accounting Forum, 37(1), 29-39.

DeZoort, F. T., \& Lord, A. T. (1994). An investigation of obedience pressure effects on auditors' judgments. Behavioral Research in Accounting, 6(1), 1-30.

Dickens, W. T., Katz, L.F., Lang, K. \& Summers, L.H. (1989). Employee crime and the monitoring puzzle. Journal of Labor Economics, 7(3), 331- 347.

Dikolli, S. S., Mayew, W.J., \& Steffen, T.D. (2012). Honoring One's Word: CEO Integrity and Accruals Quality. Retrieved from 1\%20Manuscript $\% 2092 \% 20$ Shane $\% 20$ Dikolli $\% 20$ duke.pdf

Din, H. F. M. (2008). Survey on the Use of Fraud Risk Red Flags by Auditors Financial Crimology. Master Dissertation, Accounting Research Institute, Universiti Tekmologi MARA.

DiNapoli, T. P. (2008). Red Flags for Fraud. State of New York Office of the State Comptroller, 1-14. Retrieved from https://www.osc.state.ny.us/localgov/pubs/red flags fraud.pdf

Dirsmith, M. W., \& Covaleski, M. A. (1985). Informal communications, nonformal communications and mentoring in public accounting firms. Accounting, Organizations and Society, 10(2), 149-169.

Field, A. (2000). Discovering Statistics using SPSS for Windows Sage Publications. London.

Galbraith, S., \& Stephenson, H. B. (1993). Decision rules used by male and female business students in making ethical value judgments: Another look. Journal of Business Ethics, 12(3), 227-233

Haron, H., Ismail, I., \& Abdul Razak, S. H. (2011). Factors Influencing Unethical Behavior of Insurance Agents. International Journal of Business and Social Science, 2(1), 1-17.

Hartman, L. P., DesJardins, J. R., \& MacDonald, C. (2014). Business ethics: Decision making forpersonal integrity and social responsibility (3rd ed.). New York: McGraw-Hill Higher Education.

Hasnan, S., Abdul Rahman, R. \& Mahenthrian, S., (2008). Management Predisposition, Motive, Opportunity, and Earnings Management for Fraudulent Financial Reporting in Malaysia. doi: http://dx.doi.org/10.2139/ssrn.1321455

Holtfreter, K. (2004). Fraud in US organisations: An examination of control mechanism. Journal of Financial Crime, 12(1) $88-95$.

Hooper J. M., \& Forneli C. M. (2010). Deterring and detecting financial reporting fraud-a platform for action. Center for Audit Quality, Washington D.C. Retrieved from http://www.thecaq.org/deterring-and-detecting-financial-reportingfraud 
Hunt, S. D., Wood, V. R., \& Chonko, L. B. (1989). Corporate ethical values and organizational commitment in marketing. The Journal of Marketing, 53(3), 79-90.

Irianto, G., Novianti, N., Rosalina, K., Firmanto, Y. (2009). Integrity, unethical behavior, and tendency of fraud, Ekuitas: Jurnal Ekonomi dan Kenangan, 6(2), 144-163.

Kalshoven, K., Den Hartog, D. N., \& De Hoogh, A. H. (2011). Ethical leadership at work questionnaire (ELW): Development and validation of a multidimensional measure. The Leadership Quarterly, 22(1), 51-69.

Kassem, R., \& Higson, A. (2012). The new fraud triangle model. Journal of Emerging Trends in Economics and Management Sciences, 3(3), 191-195.

Kennedy, K.A. (2012). An Analysis of Fraud: Causes, Prevention, and Notable Cases. Honors Theses. Paper 100. University of New Hampshire. from http://scholars.unh.edu/cgi/viewcontent.cgi?article=1099\&context=honors

Klein, R. (2015). How to Avoid or Minimize Fraud Exposures, The CPA Journal, March, 6-11. Retrieved from https:/ / www.nysscpa.org/news/publications/the-cpa-journal/article-preview?ArticleID=9992

KPMG. (2003). Fraud survey 2003. Retrieved from: http:/ / faculty.usfsp.edu

KPMG. (2010). Fraud and Misconduct Survey 2010. Retrieved from: http://www.kpmg.com

KPMG. (2013). KPMG Malaysia Fraud, Bribery and Corruption survey 2013. Retrieved from: https://assets.kpmg.com/content/dam/kpmg/pdf/2016/03/fraud-survey-report.pdf

Kranacher, M. J., Riley, R., \& Wells, J. T. 2010. Forensic accounting and fraud examination (1 ${ }^{\text {st }}$ edition). John Wiley \& Sons.

Kula, V., Yilmaz, C., Kaynar, B., \& Kaymaz, A. R. (2011). Managerial Assessment of Employee Fraud Risk Factors Relating to Misstatements Arising From Misappropriation of Assets: A Survey of ISE Companies. International Journal of Business and Social Science, 2(23), 171-180.

Laczniak, G.R. (1993). Marketing ethics: onward toward greater expectations. Journal of Public Policy \& Marketing, 12(1), 91-96.

Lister, L. M. (2007). A practical approach to fraud risk: Comprehensive risk assessments can enable auditors to focus antifraud efforts on areas where their organization is most vulnerable. Internal Auditor, 64(6), 61-66.

Lord, A. T., \& DeZoort, F. T. (2001). The impact of commitment and moral reasoning on auditors' responses to social influence pressure. Accounting, Organizations and Society, 26(3), 215-235.

Lou, Y.-I., \& Wang, M.-L. (2011). Fraud risk factor of the fraud triangle assessing the likelihood of fraudulent financial reporting. Journal of Business \& Economics Research, 7(2), 54-63.

Manurung, D. T., \& Hadian, N. (2013). Detection fraud of financial statement with fraud triangle. Paper presented at the 23rd International Business Research Conference, Melbourne, Australia. Retrieved from http://repository.widyatama.ac.id/xmlui/bitstream/handle/123456789/3554/1384683788 108Daniel.pdf?sequence $=1$

Marquet, C. T. (2011). The top 10 embezzlement cases in modern US history. Retrieved from http://www.marquetinternational.com/pdf/top 10 embezzlement cases in us history.pdf

Mathenge, G.D. (2014). An Empirical study to Measuring Corruption and Integrity in Kenyan Police Agency: An Ethical Perspective. Public Policy and Administration Research, 4(2), 67-79.

Menezes, A. (2014, August 21). Malaysian Couple Charged With Stealing From Bank Accounts Of Missing MH370 Passengers. International Business Times. Retrieved September 11, 2016, from http:/ / www.ibtimes.com/malavsiancouple-charged-stealing-bank-accounts-missing-mh370-passengers-1664784

Mohamed, N., Ab Majid, R., Haron, R., Jomitin, B. \& Omar, N. B. (2014). Misappropriation of assets: Tales of two cities. 2014 International Conference on Economics, Management and Development. Retrieved from http://www.europment.org/library/2014/interlaken/bypaper/ECON/ECON-26.pdf

Monica, S. E. (2013). Fraud risk management-human rationalization assessment. Business Excellence and Management, $3(1), 41-56$.

Murdock, H. (2008). The three dimensions of fraud: Auditors should understand the needs, opportunities, and justifications that lead individuals to commit fraudulent acts. Internal Auditor, 65(4), 81-83.

Murphy, P.R. \& Dacin, M.T. J (2011). Psychological Pathways to Fraud: Understanding and Preventing Fraud in Organizations. Journal of Business Ethics, 101(4), 601-618

Nunnally, J. C. (1978). Psychometric theory (2 ${ }^{\text {nd }}$ ed.). New York: McGraw-Hill. 
Omar, N. B., \& Din, H. F. M. (2010). Fraud diamond risk indicator: An assessment of its importance and usage. 2010 International Conference on Science and Social Research (CSSR 2010), December 5 - 7, 2010, Kuala Lumpur, Malaysia. Retrieved from http://ieexplore.ieee.org/stamp/stamp.jsp?arnumber $=5773853$

Pallant, J. (2007). SPSS Survival Manual (3 ${ }^{\text {rd }}$ ed.). New York: McGraw-Hill Education.

PriceWaterHouseCoopers, PWC (2014). Economic crime: A threat to business globally. Retrieved from https://www.pwc.com/gx/en/economic-crime-survey/pdf/pwc-latin-america-economic-crime-survey.pdf

Rae, K., \& Subramaniam, N. (2008). Quality of internal control procedures: Antecedents and moderating effect on organisational justice and employee fraud. Managerial Auditing Journal, 23(2), 104-124.

Ramazani, M. \& Atani, H. R. (2010) Iranian Accountants' Conception of the Prevention Methods of Fraud and Offering Some Recommendations to Reduce Fraud in Iran. Global Journal of Management and Business Research, $10(6), 31-45$.

Ramos, M. (2003). Auditors' responsibility for fraud detection. Journal of Accountancy, 195(1), 28-36.

Rezaee, Z. (2005). Causes, consequences, and deterence of financial statement fraud. Critical Perspectives on Accounting, 16(3), 277-298.

Rezaee, Z. (2005). Causes, consequences, and deterence of financial statement fraud. Critical Perspectives on Accounting, 16, 277-298.

Rockness, H., \& Rockness, J. (2005). Legislated ethics: From Enron to Sarbanes-Oxley, the impact on corporate America. Journal of Business Ethics, 57(1), 31-54.

Ruin, J. E. (2009). Internal auditing: Supporting risk management, fraud awareness management and Corporate Governance. Leeads Publication.

Sanusi, Z.M., Mohamed, N., Omar, N., \& Nasir, M. (2015). Effect of Internal Controls, Fraud Motives and Experience in Assessing Likelihood of Fraud Risk. Journal of Economic and Management, 23(2), 194-200.

Shelton, A. M. (2014). Analysis of capabilities attributed to the fraud diamond (Undergraduate Honours Theses, Paper 213). Retrieved from http://dc.etsu.edu/cgi/viewcontent.cgi?article=1211\&context=honor

Skousen, C. J., \& Wright, C. J. (2006). Contemporaneous risk factors and the prediction of financial statement fraud. Retrieved from https://papers.ssrn.com/sol3/papers.cfm?abstract $\mathrm{id}=938736$

Slezak, K. (2013). Fraud Prevention and Employee Rationalization in New York State Public Schools. Department of Educational Administration And Policy Studies University at Albany, New York. Phd Thesis. Retrieved from http://pqdtopen.proquest.com/doc/1504639871.html?FMT=AI

Smith, T. (2005). Institutional and social investors find common ground. Journal of Investing, 14(3), 57-65.

Tsang, J. (2002). Moral rationalization and the integration of situational factors and psychological processes in immoral behavior. Review of General Psychology, 6(1), 25-50.

Tugas, F. C. (2012). Exploring a new element of fraud: A study on selected financial accounting fraud cases in the world. American International Journal of Contemporary Research, 2(6), 112-121.

Vinten, G. (2003) "Enronitis - dispelling the disease", Managerial Auditing Journal, 18(6/7), 448-455

Vona, L. W. (2012). Fraud risk assessment: building a fraud audit program: John Wiley.

Wallis, D., \& Roselli, L. (2015). Breaking the cycle of fraud: what senior financial excutives should do. Retrieved from http://www.financialexecutives.org/ferf/download/2015\%20Final/2015-001.pdf

Wells, J. T. (2001). Why Employees Commit Fraud: It's either greed or need. Journal of Accountancy, 191(2), $129-92$.

Wilson, R. A. (2004). Employee dishonesty: National survey of risk managers on crime. Journal of Economic Crime Management, 2(1), 1-25.

Wolfe, D. T., \& Hermanson. D. R. (2004). The fraud diamond: Considering the four elements of fraud. CPA Journal, $74(12), 38-42$.

Zahra, S. A. (2007). Understanding the causes understanding the causes management fraud. Human Resource Management International Digest, 15(7), 122-139.

Zandstra, G. (2002). Enron, board governance and moral failings. Corporate Governance: The International Journal of Business in Society, 2(2), 16-19.

Ziegenfuss, D. E. (1996). State and local government fraud survey for 1995. Managerial Auditing Journal, 11(9), 50-55. 


\section{APPENDIX: ITEMS OF THE VARIABLES}

\begin{tabular}{|c|c|c|c|}
\hline $\begin{array}{l}\text { Dimens } \\
\text { ion }\end{array}$ & Code & Items & Factor \\
\hline \multirow{5}{*}{ 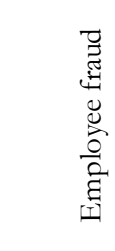 } & EFI & Misuse of organization asset/ resources & 0.897 \\
\hline & EF2 & Misuse of office time & 0.802 \\
\hline & EF3 & Non-compliance to policies & 0.789 \\
\hline & EF4 & Stealing of cash/cash equivalent & 0.865 \\
\hline & EF5 & Engaging in financial fraud & 0.799 \\
\hline \multirow{6}{*}{ 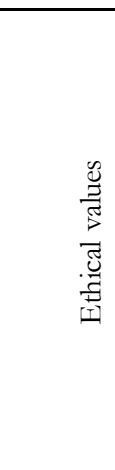 } & EV2 & $\begin{array}{l}\text { I do not normally compromise with my ethical principles. } \\
\text { When a choice has to be made between what is right and what benefits me, I would choose what is } \\
\text { right. }\end{array}$ & 0.776 \\
\hline & EV3 & My ethical action depends on the situation I am in. & 0.811 \\
\hline & EV4 & The more I think about a situation, the more ethical my decision will be. & 0.804 \\
\hline & $\mathrm{EV} 5$ & My definition about what is right or wrong depends entirely on my personal belief. & 0.799 \\
\hline & EV6 & $\begin{array}{l}\text { I should be allowed to form my own ethical standards because ethical consideration varies from one } \\
\text { individual to another. }\end{array}$ & 0.817 \\
\hline & EV7 & $\begin{array}{l}\text { I will not tell the truth if I know that I will have to pay a price for it. } \\
\text { A code of ethics among organizations cannot be standardized because each individual has different } \\
\text { perspective between what is right and wrong. }\end{array}$ & 0.898 \\
\hline \multirow{8}{*}{ 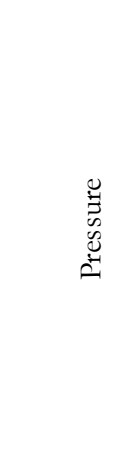 } & P1 & My work pressure is high. & 0.888 \\
\hline & P2 & $\begin{array}{l}\text { My work needs me to achieve KPI given by the company (e.g., target, achievement, workload, } \\
\text { waiting time, audit, time frame, and review). }\end{array}$ & 0.799 \\
\hline & P3 & I have much work that must be done simultaneously. & 0.89 \\
\hline & P4 & I am faced with tension and depression because of the constant pressure at work. & 0.801 \\
\hline & P5 & $\begin{array}{l}\text { Expenses on necessities need to be cut off to ensure that my salary will be sufficient until the end of } \\
\text { the month. }\end{array}$ & 0.824 \\
\hline & P6 & Family expenses are extremely costly, which I cannot afford to pay in some cases. & 0.865 \\
\hline & P7 & I am fully responsible to support my family financially. & 0.832 \\
\hline & P8 & I need to hold my monthly debt payment in some cases because I do not have sufficient cash to pay. & 0.826 \\
\hline \multirow{8}{*}{ 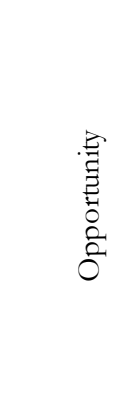 } & OI & Every transaction done has sufficient documentation and approval. & 0.889 \\
\hline & $\mathrm{O} 2$ & Transactions are being entered in a timely manner. & 0.912 \\
\hline & $\mathrm{O} 3$ & Transactions are being recorded in the correct accounting period. & 0.798 \\
\hline & $\mathrm{O} 4$ & Separation of roles and responsibilities is clear. & 0.991 \\
\hline & O5 & Proper supervision, monitoring, and review of work are implemented. & 0.888 \\
\hline & O6 & Policies, procedures, and guidelines are well documented. & 0.86 \\
\hline & $\mathrm{O} 7$ & Cash boxes are strongly secured. & 0.81 \\
\hline & O8 & Closed-circuit television (CCTV) is used to monitor entries and exits. & 0.996 \\
\hline \multirow{8}{*}{ 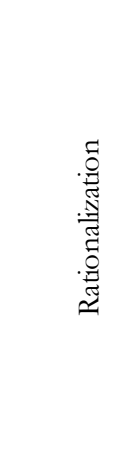 } & RI & I think that I am underpaid with the amount of responsibility given to me. & 0.901 \\
\hline & $\mathrm{R} 2$ & I believe I must save a family member or loved one who is need of financial aid. & 0.802 \\
\hline & R3 & I believe I am in a desperate financial situation & 0.812 \\
\hline & R4 & No one will suffer if I use the office facilities for personal purpose & 0.799 \\
\hline & $\mathrm{R} 5$ & I am only borrowing the asset of the office, and I will return it back when I am done. & 0.8 \\
\hline & R6 & $\begin{array}{l}\text { I believe that a gift from a customer, a vendor, or a colleague is a gesture of good service rend ered } \\
\text { by me. }\end{array}$ & 0.812 \\
\hline & $\mathrm{R} 7$ & I believe that I should be given some discretion in performing my job. & 0.877 \\
\hline & $\mathrm{R} 8$ & $\begin{array}{l}\text { Some discretion on policies and procedure sometimes should be tolerated to help a customer, a } \\
\text { vendor, or a colleague. }\end{array}$ & 0.831 \\
\hline
\end{tabular}

